\title{
Perception of Rural Dwellers on the Nutritional and Medicinal Values of Moringa oleifera in Ido Local Government of Oyo State
}

\author{
${ }^{* 1}$ Osewa S.O., ${ }^{2}$ Adeniran A.A., ${ }^{1}$ Alamu O., ${ }^{1}$ Olubiyi M.R., \\ ${ }^{2}$ Adeloju A.
}

\author{
${ }^{1}$ National Centre for Genetic Resources and Biotechnology (NACGRAB), P.M.B 5382 Moor \\ Plantation, Ibadan, Nigeria. \\ ${ }^{2}$ Federal College of Agriculture, Moor Plantation, Ibadan.
}

Article No.: 060913823

DOI: 10.15580/GJAS.2013.12.060913823

Submitted: 09/06/2013

Accepted: 22/12/2013

Published: 29/12/2013

${ }^{*}$ Corresponding Author

Osewa S.O.

E-mail: sundayosewa @yahoo.com

\section{Keywords:}

perception, awareness, utilization, sources of information, nutritional and medicinal values
The study investigated the perception of rural dwellers on nutritional and medicinal values of Moringa oleifera in Ido Local Government Area of Oyo State, Nigeria, with the specific objectives of assessing the demographic characteristics of rural dwellers. Also, to determine the level of awareness of nutritional and medicinal values of Moringa, identify the various ways in which respondents consume Moringa, assessing rural dwellers' sources of information and identify the perceived nutritional and medicinal benefits of Moringa in the study area. A purposively sampling technique was used to collect information with the aid of structured questionnaire from 120 respondents. Data collected were analyzed using frequency counts and percentages. The study reveals that more than half of the respondents were mostly male $(53.3 \%)$, married $(60 \%)$, while majority of them had some form of formal education. Majority $(40.8 \%)$ of the respondents preferred taken powdered leaves. The study showed that half $(50.0 \%)$ and $42.5 \%$ of the respondents had access to information through friends/relatives and radio respectively on the utilization of Moringa. It was recommended that the government should try to minimize the constraints encountered by the rural dwellers in the consumption of Moringa by providing the basic amenities necessary for life in rural areas and rural dwellers should be motivated through credit facilities and series of training on cultivation and utilization of Moringa. 


\section{INTRODUCTION}

Moringa is a tropical plant belonging to the family Moringacaea and grows throughout the tropics. The genus Moringa consists of 13 species (NRC, 2006), of which only Moringa oleifera has been accorded research and development. Moringa (Moringa oleifera Lam.) is native to the Indian subcontinent and has become naturalized in the tropical and subtropical areas around the world. It is the most widely cultivated species of the genus Moringa. The tree is known by such regional names as Benzolive, Drumstick tree, Horseradish tree, Kelor, Marango, Mlonge, Mulangay, Saijihan and Sajna (Fahey, 2005) and grows quickly in many types of environments. It can grow well in the humid tropics or hot dry lands and can survive in less fertile soils and it is a little affected by drought (Anwar et al., 2007). It is considered as one of the World's most useful trees, as almost every part of the Moringa tree can be used for food, medication and industrial purposes (Khalafalla et al., 2010).

Much of the plant is edible by humans or by farm animals. The leaves are rich in protein, vitamin $A$, vitamin $B$, vitamin $C$ and minerals (Janick, Jules and Robert, 2008). It common names include moringa, benzolive tree and West Indian ben. It is also known as drumstick tree, from the appearance of the long slender, triangular seed pods, horseradish or ben oil tree.

Moringa oleifera is a shrub with numerous benefits especially in the treatment of human and animal health. Every part of Moringa, including the seeds and roots are very useful in tackling many diseases. People use its leaves, flowers and fresh pods as vegetables, while others use it as livestock feed (Anjorin et al., 2010). It is commonly grown for its leaves, which are used in soup, while in some region, the young seed pods are the most commonly eaten (FAO, 1999). The flowers are edible when cooked and are said to taste like mushrooms. The bark, sap, roots, leaves, seeds, oil, and flowers are used in traditional medicine in several countries. The immature seed pods are prepared by parboiling and cooked in a sauce until soft (Elizabeth Schneider, 2001). The seed pods are particularly high in vitamin C. According to USDA, the leaves are the most nutritious part of the plant, being a significant source of vitamin $B_{6}$, vitamin $\mathrm{C}$, provitamin $\mathrm{A}$ as beta-carotene, magnesium and protein, among other nutrients. When compared with common foods particularly high in certain nutrients, fresh moringa leaves are considerable sources of these same nutrients (Fugile, 1999).

Moringa is a food, medicine and forage crop and the health benefit of moringa is limitless. It is a strong antioxidant effective against prostrate and skin cancers.
It is an anti-tumour and anti-ageing substance. It modulates anemia, high blood pressure, diabetes, high serum or blood cholesterol thyroid, liver and kidney problems. It has strong anti-inflammatory properties ameliorating rheumatism, arthritis, edema and lupus. It is effective against digestive disorders including colitis, diarrhea, flatulence -gas, ulcer or gastritis. Moringa is an anti-bacterium, anti-microbial and anti-viral agent, it is effective against urinary tract infection, typhoid, syphilis, dental carries and toothaches, fungus, thrush, common cold, Epsetein-Barr virus, Herpes-simplex, HIV, warts parasites, worms, schistosomes and trypanosomes. It is a detoxifying agent, it is effective against snake and scorpion bites.

It has been observed that the threat of famine is connected to the change of climate. The problem of poverty in developing countries like Nigeria has always give rise to other problems, which include malnutrition and food insecurity especially in the rural areas, where malnutrition is most prevalent. However, in developing countries, moringa has been potentially found to improve nutrition, boost food security, foster rural development and support sustainable landrace (NRC, 2006). Moringa oleifera is a multipurpose tree that has amazing nutritional, therapeutic and prophylactic potentials. It is especially promising as a food source in the tropics because of the substantial or numerous health benefits realized by consumption of moringa in situation where starvation is imminent (Fahey, 2005; Sanford Holst, 2011). Moringa tree has been used to combat malnutrition, especially among infants and nursing mothers, and as a result regarded as natural nutrition for the tropics (Fugile, 1999).

Moringa is one of the world's most nutritious crops and it is being cultivated in poverty-stricken nations, such as Niger, as a primary source of food and nutrients (www.abc.net.au/worldtoday/content/2012). The leaves contain all the essential amino acids and a wealth of essential nutrients and even thrive well in poor soil conditions and the tree is an outstanding source of nutrition, especially in areas where other food sources are scarce or seasonally unavailable and can grow in a wide of tropical and semi-arid climates, making a viable solution for areas affected by food shortages and populations susceptible to malnutrition. Moringa leaves could practically wipe out malnutrition in the world.

Since foods consumed by the people often affect their well being, there is need to find if any relationship exists between their perception of nutritional and medicinal values of the Moringa they consume and level of consumption of Moringa. In this light, this study will seek answers to these research questions such as:

1. What are the personal characteristics of rural dwellers in the study area?

2. What is the level of awareness of nutritional and medicinal values of Moringa?

3. What are the various ways in which they consume Moringa?

4. What are rural dwellers' present sources of information on utilization of Moringa?

5. What are the perceived nutritional and medicinal benefits of Moringa in the study area? 


\section{METHODOLOGY}

\section{Study Area}

The study was conducted in Ido Local Government of Oyo State, Nigeria. Its headquarters are in the town of Ido. It has an area of $986 \mathrm{~km}^{2}$ and a population of 103,261 at the 2006 census. It was created out of the old Akinyele local government in 1989. Agriculture is the main occupation in this area; some of the livestock reared include Cattle, sheep, goat, swine, rabbit and snail as well as fish. Their secondary occupations are trading, craftworks, blacksmith, gaari and oil processing. Presently, Ido local government is the largest producer of Cocoa in Oyo state.

\section{Sampling Procedure and Sample Size}

The population involved in this study consisted of rural dwellers in Ido Local Government Area of Oyo State. The choice of Ido LGA for this research was due to its well known agricultural activities. For this study, out of the villages in Ido Local Government, five (5) villages were randomly sampled and these villages are Akufo, Bakatari, Idi-amu, Olokuta and Maku. Each selected villages consist of approximately 240 rural dwellers, $10 \%$ of the respondents were selected from these five villages given a total of 120 respondents.

\section{Data collection and analysis}

Data were collected from the primary sources with the aid of a structured interview schedule. The data collected were analyzed with the aid of the descriptive statistical tools of frequency counts and percentage. An inferential tool, Chi-square $\left(X^{2}\right)$ and Pearson Product Moment Correlation (PPMC) were used to analyze the study hypotheses. The hypotheses were stated in null form $\left(\mathrm{H}_{\mathrm{o}}\right)$ :

$\mathrm{Ho}_{1}$ : There is no significant relationship between the rural dwellers personal characteteristics and perceived nutritional and medicinal values of Moringa.

$\mathrm{Ho}_{2}$ : There is no significant relationship between the rural dwellers' sources of information and perceived nutritional and medicinal values of Moringa.

$\mathrm{Ho}_{3}$ : There is no significant relationship between respondents' level of awareness and perceived nutritional and medicinal values of Moringa.

\section{RESULTS AND DISCUSSION}

\section{Demographic characteristics of the respondents}

The selected personal characteristics of the respondents considered include age, sex, marital status, level of education, religion, household size, access and source of credit.

Table 1 Shows that $25 \%$ of the respondents fall between $20-29$ years, majority (27.5\%) is within the age bracket $30-39$ and $20.8 \%$ fall within 40 and 49 years, $12.5 \%$ fall within 50 and 59 years, while only (5\%) are within 70 years and above. This shows that the respondents are young, active and energetic. Sex on the other hand, is an essential factor in agricultural set up. The productive activities of males and females in agricultural development are very important and must be taken into consideration at every point in time. This study shows that more than half $(53.3 \%)$ of the respondents are male while $46.7 \%$ are female. Also, the study shows that majority $(61.7 \%)$ of the respondents are Christians, $36.7 \%$ are Moslems, while only $1.7 \%$ are traditionalists. This means that both Christians and Muslims were knowledgeable about the existence of Moringa. Majority $(60.0 \%)$ of the respondents are married, $25.8 \%$ are single and $7.5 \%$ are widowed while only $6.7 \%$ are divorced. This study implies that majority of the respondents are married and have responsibilities of their households to meet. The predominance of married respondents suggests that they may be deriving some form of support from family members. Moreover, this study shows that $34.2 \%$ of the respondents had secondary education, $33.3 \%$ had tertiary education, while $18.3 \%$ and $14.2 \%$ had secondary primary and no formal education respectively. The high literacy among respondents may enhance adoption of innovations on moringa.

\section{Respondents awareness level of nutritional and medicinal values of Moringa}

Table 2 shows that most (95.8\%) of the respondents aware that moringa leaves is highly proteinous, $88.3 \%$ believed that moringa leaves are eaten as a vegetable soup and $87.5 \%$ agreed that it is very effective in curing headaches. $85 \%$ of the respondents agreed that it is very effective in the treatment of fever, while $60 \%$ aware that it could be used to treat both eye and ear infections.

However, the table 3 shows the two categories (i.e. high and low) at which respondents are being aware of nutritional and medicinal values of Moringa. The result of the analysis as indicated on the table shows that more than half $(55.8 \%)$ of the respondents are quite aware of both nutritional and medicinal values of Moringa. Therefore, the level of awareness is high and hence, there is little need to create more awareness on the usefulness of Moringa.

\section{Frequency of Moringa consumption}

The study (Table 4 )shows that majority (40.8\%) always taken powdered leaves, while $4.3 \%$ has never taken. $36.7 \%$ of the respondents always taken when dried and crushed into powder to make soups and sauce, while 
only $5 \%$ has never taken it. Moreover, $28.3 \%$ always roots and leaves when boiled, while only $2.5 \%$ has never taken it. Also, 30.8\% always taken leaves when cooked, while only $4.2 \%$ had never taken it.

\section{Sources of information on utilization of Moringa}

This study shows that half $(50.0 \%)$ of the respondents had access to information through friends/relatives on a regular basis on the utilization of Moringa. Moreover, $42.5 \%$ had access to information through radio on a regular basis. However, only $6.7 \%$ had access to information through mobile phone on a regular. The finding that about $94 \%$ of respondents used radio as an information source supports the findings of FAO (1989) who observed that radio was among the electronic media used successfully in rural areas.

\section{Perceived nutritional and medicinal benefits of Moringa}

Table 6 shows that the majority of the respondents strongly agreed and agreed on the nutritional and medicinal values of Moringa, a few of them were undecided for all the perception statement. Thus, critically analyzing this, it can be seen that there is a strong positive perception of the respondents. There is favourable $(63.3 \%)$ perception of nutritional and medicinal values of Moringa.

\section{Testing of Hypotheses}

Hypothesis one $\left(\mathrm{Ho}_{1}\right)$ : There is no significant relationship between rural dwellers personal characteristics and perceived nutritional and medicinal benefits of Moringa. Result in table 7 shows that there is no significant relationship between respondents' perception of medicinal and nutritional values and age $(r$ $=-0.490, p=0.593)$, religion $(r=0.684, p=0.759 a)$, educational attainment $(r=0.334, p=3.403 a)$. The null hypothesis for each of the selected characteristics above was accepted, while there is a significant relationship relationship between marital status $\left(\chi^{2}=0.598, p=\right.$ $1.880 \mathrm{a})$ and perceived nutritional and medicinal benefits of Moringa. Therefore, the null hypothesis was rejected. This indicates that the older people have favourable perceptions toward nutritional and medicinal values of Moringa.

Hypothesis Two $\left(\mathrm{Ho}_{2}\right)$ : There is no significant relationship between the rural dwellers' sources of information and perceived nutritional and medicinal benefits of Moringa. Table 8 result shows that there is a significant relationship between the rural dwellers' sources of information and perceived nutritional and medicinal benefits of Moringa ( $r=0.252$ and $p=0.038$ ). Therefore, the null hypothesis is rejected. It implies that the exposure of the respondents to information sources have perceived effect on nutritional and medicinal benefits of Moringa.

Hypothesis Three $\left(\mathrm{Ho}_{3}\right)$ : There is no significant relationship between respondents' level of awareness and perceived nutritional and medicinal benefits of Moringa. Table 8 shows that there is a significant relationship between respondents' level of awareness and perceived nutritional and medicinal values of Moringa ( $r=0.390$ and $p=0.033)$.

\section{CONCLUSION}

It is concluded that the health benefit of moringa is limitless and the majority of the respondents are male, middle-aged, married, with no formal education. Majority of the respondents aware that moringa leaves is highly proteinous and rich in Vitamin A, B, C and minerals, leaves are either taken fresh, dried and cooked, respondents had access to information through friends/relatives on a regular basis on the utilization of Moringa. They speak Yoruba fluently and Moringa does not have any religious taboos while its acceptability cut across both religious and cultural beliefs.

\section{RECOMMENDATIONS}

Based on the conclusions of this study, it is therefore recommended that the government should make public awareness on cultivation of Moringa in the rural areas and be motivated through credit facilities and series of training on cultivation and utilization of Moringa in order to ensure sustainable production of this important crop. 
Table I: Distribution of selected personal characteristics of the processors $(\mathrm{N}=120)$

\begin{tabular}{lcc}
\hline variables & Frequency & Percentage \\
\hline Age & 30 & \\
$20-29$ & 33 & 25.0 \\
$30-39$ & 25 & 27.5 \\
$40-49$ & 15 & 20.8 \\
$50-59$ & 11 & 12.5 \\
$60-69$ & 6 & 9.2 \\
70 and above & & 5.0 \\
Sex & 64 & 53.3 \\
Male & 56 & 46.7 \\
Female & 74 & 61.7 \\
Religion & 44 & 36.7 \\
Christianity & 2 & 1.7 \\
Moslem & & \\
Traditional & 72 & 60.0 \\
Marital status & 31 & 25.8 \\
Married & 8 & 6.7 \\
Single & 9 & 7.5 \\
Divorced & & \\
Widow & 17 & 14.2 \\
Education attainment & 22 & 18.3 \\
Non - formal & 41 & 34.2 \\
Primary education & 40 & 33.3 \\
Secondary education & &
\end{tabular}

Source: Field survey, 2012

Table II: Distribution of respondents' level of awareness ( $\mathrm{N}=120)$

\begin{tabular}{lcc}
\hline Uses & Frequency & Percentage \\
It is highly proteinous & 115 & 95.8 \\
Rich in Vitamin A, B, C and minerals & 111 & 92.5 \\
Leaves are eaten as vegetable soup & 106 & 88.3 \\
Proven to be effective in curing headaches & 105 & 87.5 \\
Effective treatment of fevers & 102 & 85 \\
It is proven to treat eye and ear infections & 72 & 60 \\
proven to stop bleeding & 99 & 82.5 \\
Proven to treat anemia & 94 & 78.3 \\
Leaf can be used to treat gastric ulcers and diarrhea & 89 & 74.2 \\
Leaves are readily eaten as forage for animals & 85 & 70.8 \\
Seed has been proven to treat arthritis & 91 & 75.8 \\
Seed contains oil used in cooking and acceptable to taste & 99 & 82.5 \\
Seed has been proven to treat sexually transmitted diseases & 85 & 70.8 \\
Seed has been proven to treat boils & 93 & 77.5 \\
Seeds are used for treating erectile dysfunction in men & 96 & 80 \\
Seed can be used as a relaxant for epilepsy & 98 & 81.7 \\
Flower juice is useful to solve urinary problems & 100 & 83.3 \\
Bark is an appetizer & 79 & 65.8 \\
\hline Sourc: Field surver 2012 & &
\end{tabular}

Source: Field survey, 2012

Table III: Categorization of nutritional and medicinal values of Moringa awareness

\begin{tabular}{l|l|l}
\hline Level & Frequency & Percentage \\
Low $(<$ mean) & 53 & 44.2 \\
High $(\geq$ mean $)$ & 67 & 55.8 \\
Total & 120 & 100 \\
\hline
\end{tabular}

Source: Field survey, 2012 
Table IV: Distribution of respondents' frequency of consumption of Moringa

\begin{tabular}{|c|c|c|c|c|}
\hline \multirow{4}{*}{$\begin{array}{l}\text { Consumption of Moringa } \\
\text { Powdered leaves taken } \\
\text { leaves eaten dried, crushed into } \\
\text { powder to make soups \& sauce } \\
\text { roots and leaves boiled }\end{array}$} & Always(\%) & Occasionally(\%) & Rarely(\%) & Never(\%) \\
\hline & $49(40.8)$ & $45(37.5)$ & $22(18.3)$ & 4(3.3) \\
\hline & 44 (36.7) & $46(38.3)$ & $24(20.0)$ & $6(5.0)$ \\
\hline & 34 (28.3) & 47 (39.2) & $36(30.0)$ & $3(2.5)$ \\
\hline \multirow{2}{*}{$\begin{array}{l}\text { bark, roots and leaves boiled } \\
\text { leaves eaten cooked }\end{array}$} & 35 (29.2) & $61(50.8)$ & $22(18.3)$ & $2(1.7)$ \\
\hline & $37(30.8)$ & $62(51.7)$ & 16 (13.3) & $5(4.2)$ \\
\hline leaves eaten fresh & $20(16.7)$ & 76 (63.3) & $24(20.0)$ & - \\
\hline $\begin{array}{l}\text { leaves cooked used for seasoning } \\
\text { foods }\end{array}$ & $25(20.8)$ & $61(50.8)$ & $31(25.8)$ & $3(2.5)$ \\
\hline
\end{tabular}

Table V: Percentage distribution of respondents based on their sources of information on utilization of Moringa $(n=120)$

\begin{tabular}{|c|c|c|c|}
\hline \multirow[t]{2}{*}{ Information sources } & \multicolumn{3}{|c|}{ Frequency of access } \\
\hline & Regular (\%) & Occasional (\%) & Never (\%) \\
\hline Extension agents & 9.2 & 42.5 & 48.3 \\
\hline Radio & 42.5 & 48.3 & 8.3 \\
\hline Farmers association & 33.3 & 51.7 & 15.0 \\
\hline Friends/Relatives & 50.0 & 35.5 & 15.0 \\
\hline Television/Video & 21.7 & 34.2 & 44.2 \\
\hline Newspapers/Pamphlets & 17.5 & 35.0 & 47.5 \\
\hline Mobile phone & 6.7 & 28.3 & 65.0 \\
\hline Internet & 17.5 & 34.2 & 48.3 \\
\hline
\end{tabular}

Source: Field survey, 2012

\begin{tabular}{|c|c|c|c|c|c|c|}
\hline SN & Benefits & SA & A & $\mathbf{U}$ & D & SD \\
\hline 1 & Moringa contains all amino acids & $36(30)$ & $79(65.8)$ & $4(3.3)$ & $1(0.8)$ & - \\
\hline 2 & It helps in food digestibility & $75(62.5)$ & $39(32.5)$ & $5(4.2)$ & $1(0.8)$ & - \\
\hline 3 & Moringa is a very good natural energy booster & $54(45)$ & $59(49.2)$ & $7(5.8)$ & & - \\
\hline 4 & $\begin{array}{l}\text { It has antibiotic properties, which is effective against } \\
\text { many infectious organisms }\end{array}$ & $37(30.8)$ & $71(59.2)$ & $9(7.5)$ & $3(2.5)$ & - \\
\hline 5 & Moringa is good for making food seasoning & $53(44.2)$ & $61(50.8)$ & $5(4.2)$ & & . \\
\hline 6 & $\begin{array}{l}\text { It cures headaches and migraines with high } \\
\text { effectiveness and immediacy. }\end{array}$ & $31(25.8)$ & $75(62.5)$ & $11(9.2)$ & $3(2.5)$ & - \\
\hline 7 & $\begin{array}{l}\text { Moringa provides good nourishment by supplying all } \\
\text { essential nutrients to the body. }\end{array}$ & $8(6.7)$ & $8(6.7)$ & $\begin{array}{l}27(22 . \\
5)\end{array}$ & $\begin{array}{l}52(43 . \\
3)\end{array}$ & $\begin{array}{l}25(20 . \\
8)\end{array}$ \\
\hline 8 & Moringa will rather pollute water than purify it & $8(6.7)$ & $8(6.7)$ & $\begin{array}{l}27(22 . \\
5)\end{array}$ & $\begin{array}{l}52(43 . \\
3)\end{array}$ & $\begin{array}{l}25(20 . \\
8)\end{array}$ \\
\hline 9 & $\begin{array}{l}\text { Moringa provides good alternative in the treatment of } \\
\text { rheumatism }\end{array}$ & $21(17.5)$ & $79(65.8)$ & $\begin{array}{l}14(11 . \\
7)\end{array}$ & $4(3.3)$ & $2(1.7)$ \\
\hline 10 & It cannot prevent human body from malaria infection & $44(36.7)$ & $51(42.5)$ & $11(9.2)$ & $11(9.2)$ & $3(2.5)$ \\
\hline 11 & That moringa can detoxify the body are all lies & $13(10.8)$ & $9(10.5)$ & $24(20)$ & $\begin{array}{l}46(38 . \\
6)\end{array}$ & $\begin{array}{l}28(23 . \\
3)\end{array}$ \\
\hline 12 & lake a good tea & $58(4$ & 41(34.2) & $8(6.2)$ & $5(4.2)$ & $8(6.2)$ \\
\hline 13 & morit & & & $6(5.0)$ & & $7(5.8)$ \\
\hline 14 & It is a nutritional supplement for HIV/AIDS patients & $13(10.8)$ & $66(55.0)$ & $\begin{array}{l}34(28 . \\
3)\end{array}$ & $5(4.2)$ & $2(1.7)$ \\
\hline 15 & Moringa can be good for increasing libido & $21(17.5)$ & $69(57.5)$ & $\begin{array}{l}24(20 . \\
0)\end{array}$ & $5(4.2)$ & $1(0.8)$ \\
\hline 16 & $\begin{array}{l}\text { One better seek medical advice for treating venomous } \\
\text { bites than result to Moringa }\end{array}$ & $5(4.2)$ & $4(3.3)$ & $\begin{array}{l}20(16 . \\
7)\end{array}$ & $\begin{array}{l}57(47 . \\
5)\end{array}$ & $\begin{array}{l}34(28 . \\
3)\end{array}$ \\
\hline
\end{tabular}


Table VII: Chi-square test of the relationship between selected personal characteristics and perceived nutritional and medicinal benefits of Moringa.

\begin{tabular}{|l|l|l|l|l|}
\hline Variables & r-value & p-value & Remark & Decision \\
\hline Age & -0.490 & 0.593 & NS & Accept Ho \\
\hline Religion & 0.684 & $0.759 \mathrm{a}$ & NS & Accept Ho \\
\hline Marital status & 0.598 & $1.880 \mathrm{a}$ & S & Reject Ho \\
\hline Educational attainment & 0.334 & $3.403 \mathrm{a}$ & NS & Accept Ho \\
\hline
\end{tabular}

Source: Field survey, 2012

Table VIII: PPMC results of correlation

\begin{tabular}{|l|l|l|l|l|}
\hline Variables & r-value & p-value & Remark & Decision \\
\hline Exposure to information & 0.252 & 0.038 & S & Reject Ho \\
\hline Awareness & 0.390 & 0.033 & S & Reject t Ho \\
\hline
\end{tabular}

\section{REFERENCES}

Elizabeth Schneider (2001): Vegetables from Amaranth to Zucchini; The Essential Reference, Harpercollins.

Fahey (2005). "Moringa oleifera: A Review of the Medical Evidence for Its Nutritional, Therapeutic and Prophylactic Properties, Part 1". Trees for Life Journal. Food and Agriculture Organization of the United Nations, Country Pasture/Forage Resource Profiles, Philippines.

Fugile (1999). Natural Nutrition for the Tropics. Dakar : Church World Service.

Janick, Jules, Robert E Paull (2008): The Encyclopedia of Fruit and Nuts. CABL pp.509-510.ISBN
National Research Council (2006). "Moringa". Lost Crops of Africa: National Academies Press.Volume II.

Rajangam, J. (2001): Status of production and utilization of Moringa in South India in "Development potential for Moringa Product". Oct. 29 $9^{\text {th }}-$ Nov. $2^{\text {nd }}, 2001$. Daressalam, Tanzania.

Sanford Holst (2001): Moringa (2 ed.). Santorini Publishing.ISBN.

Schwarz (2000): "Water Clarification using Moringa oleifera". Technical Information (Gate Information Service). www.abc.net.au/worldtoday/content/2012

Cite this Article: Osewa SO, Adeniran AA, Alamu O, Olubiyi MR, Adeloju A (2013). Perception of Rural Dwellers on the Nutritional and Medicinal Values of Moringa oleifera in Ido Local Government of Oyo State. Greener Journal of Agricultural Sciences, 3(12): 829-835, http://doi.org/10.15580/GJAS.2013.12.060913823. 